\title{
EENIGE OPMERKINGEN OVER SOCIALISME EN SOCIALISATIE.
}

\author{
De onnoozele gelooft elk woord, \\ maat de bedachtzame let op zijne schreden. \\ Spreuken.
}

Onze woelige tijd kenmerkt zich door een ,,versnelden polslag”, waarvan het maatschappelijk organisme blijk geeft. Dat is niets nieuws. De politieke en economische geschiedenis geeft voorbeelden te over van verhaaste, met schokken optredende evoluties, die dan revoluties heeten, waarbij een koortsachtige, bouleverseerende gejaagdheid zich van velen meester maakt, die daardoor ongeveer in gelijke reden ontoegankelijk worden voor de door de realiteit geëischte matiging en voor de waarheid van het adagium ,zij, die gelooven, haasten niet". Critiek, vooral zelfcritiek, wordt bij zulk een op een lawine, ook in de gevolgen, gelijkende gesteldheid der geesten, een steeds schaarscher vogel, en wie meent met een ontnuchterend „du denkst zu schieben, du wirst geschoben" iets tegenover de leiders uit te richten en hen te bewiegen de pasmunt hunner eenzijdigheid eens in te wisselen tegen het volwaardige standaardgeld eener algemeen geldige objectiviteit, die de gemeenschap van haren arts mag vergen, loopt àl grooter kans bedrogen uit te komen. „De geest van den tijd" is de afgod, aan wien vóór alles moet worden geofferd, wil men niet doorgaan voor achterlijk, voor een sociaal-economisch fossiel waarmee niet behoeft gerekend. Kuddegeest, valsche schaamte, doen de schare aanzwellen en dreigen de qualiteit, het relatief-goede eener beweging onder de quantiteit te verstikken. Individualiteit, eigen-meening, karaktervastheid worden steeds minder gewaardeerd,-zijn helaas maar al te vaak bij het doorgaand nivelleeringsproces, dat de dalen vult ten koste van de uitzichtgevende bergtoppen, belemmeringen om het ver in de wereld te brengen. Een typisch en tragisch voorbeeld in dezen is de politieke cameleon, die Lloyd George heet. De organisatiebacil heeft ook veel persoonlijks vernietigd.

Leuzen rijzen als paddestoelen uit den grond, sommige zijn ééndagsvliegen, andere houden het wat langer, vadk wok blijft

Econ. 1920. 
het woord nog voortleven nadat de ziel al lang geweken is en nòg vaker denkt menigeen daarbij juist datgene, wat met zijn toevallige wenschen strookt. Het is geen zeldzaam verschijnsel, dat in naam van een leus haarzelve de adem wordt afgesneden. De oorlogsleuzen van weerszijden met haar ellendige hypocrisic liggen ons nog versch in het geheugen. Vergeleken hiermede doet als een verfrisschende Meiregen aan de in uitbundige phraseologie losbarstende naieveteit der 'Fransche revolutie: „La propriété étant un droit inviolable et sacré", verg. art. 17 der „Déclaration des droits de l'homme et du citoyen", of het in zijn onmacht zoo knusse art. 7 der „Burgerlijke en Staatkundige Grondregels”, deel uitmakende van onze eerste Staatsregeling van 1798: „Niemand is een goed Burger, dan die de huiselijke pligten, in den onderscheiden stand, waarin hij moge gesteld zijn, zorgvuldiglijk uitoefent, en voords, in alle opzigten, aan zijne maatschappelijke betrekkingen voldoet". De praktijk heeft gauw genoeg den vurigen jongeling, die zich aan vrijheid, gelijkheid en broederschap een roes had gedronken, naar het politie-bureau gebracht. Toen werd hij niet beter: de leuze bleef naspoken, maar de ziel week uit. En zoo kon art. $625 \mathrm{~B}$. W. wel beginnen met den eigendom te definieeren als ,het regt om van eene zaak het vrij genot te hebben en daarover op de volstrektste ${ }^{1}$ ) wijze te beschikken", doch om te vervolgen en te besluiten met een reeks van "mitsen" en „behoudensen", die de leus zonder inhoud als een leugen in wetsvorm aan de kaak stellen.

Hetgeen alles maar zeggen wil, dat leuzen, Schlagwörter of hoe men ze noemen mag, niet veel kosten. Men is er te allen tijde dan ook zeer mild mede geweest.

Zou de in diverse toonaarden aangeheven leus der $\mathrm{zg}$. socialisatie van bedrijven tot den boven geschetsten minder au sérieux te nemen regel, of tot een der misschien wel ernstig op te vatten uitzonderingen behooren? De mate, waarin met socialisatie wordt geschermd ten overstaan van Jan Publiek, zou alle recht geven om den ernst der zaak in twijfel te trekken. De Regeering, die een soort van socialisatie-commissie en een arbeiders-medezeggenschap-commissie, op het bevorderen van den bedrijfsvrede gericht, instelde beide met den Heer Nolens tot voorzitter, deed dit niet. De zaak is zeer zeker een gezet onderzoek, in de minder voor

2) N.b. volstrekt in den superlatief. 
hartstochten toegankelijke regionen waar zulk commissinaal werk plaats heeft, ten volle waard.

Wat is onder socialisatie te verstaan ? Do heer R. Kuyper in zijn lezenswaardige rede over "Socialisme en Socialisatie" noemt de laatste: „een einde maken aan het kapitalisme, den overgang van kapitalisme tot socialisme doelbewust bewerkstelligen". Ze zou dan wezen een s. d. werkmethode, die, consequent gevolgd, tot het socialisme voert; zij ware met het socialisme niet identiek, doch zou zich daartoe verhouden als middel tot doel. Er zouden misschien andere middelen mogelijk zijn, andere wegen open staan. Maar op de socialisatie valt bij haar voorstanders dermate âlle licht, dat zij dan toch als hèt middel, als de weg wordt aanbevolen. De socialistische gemeenschapsbedrijven mogen niet worden verward met de tegenwoordige overheidsbedrijven onder het kapitalisme. Als reactionnair wordt verworpen de leuze ;,de fabriek aan de arbeiders". De gemeenschaps-eigendom en het dito beheer van grond, grondstoffen en andere productiemiddelen, de volkomen systematische voortbrenging, die bij het voortschrijden van socialisatie meer en meer veldwinnen, zijn met die leuze, volkomen begrijpelijk, onvereenigbaar. Dat socialisatie iets te maken heeft met het $\mathrm{zg}$. constitutioneel organiseeren van het bedrijf, met medezeggenschap van de arbeiders niet alleen in zake loon $\div$ en andere arbeidsvoorwaarden, arbeidstijd e.d., maar ook in de bedrijfstechnische en commercieele gestie, door middel van een gemengde vertegenwoordiging, waarin ook intellectueelen en consumenten zitting krijgen, en waarbij men zich natuurlijk de vormen en verhoudingen verschillend kan voorstellen - de fantasie heeft hier vrij spel - voelt iedereen.

Socialisatie is niets anders dan een geleidelijke gang naar het collectivisme van Karl Marx. Naar mate de weg daarheen wordt afgelegd, krimpt de kapitalistische uitbuiting, en, hoewel in langzamer tempo, van lieverlede ook het loonstelsel in, doordien de productiemiddelen, waarvan het gesocialiseerde bedrijf zich bedient, aan de gemeenschap, hetzij men deze Rijk, gemeente dan wel autonoom publiekrechtelijk bedrijf wil noemen, worden gebracht.

$\mathrm{Nu}$ allereerst de principieele vraag nopens de uitbuiting van het proletariaat of "den" arbeid door het kapitalisme. Het is mij altijd voorgekomen, dat na alle critiek, die op het meesterwerk van Marx is uitgebracht en waardoor diens theoretisch 
leergebouw tot een puinhoop is geworden, de socialistische voormannen met de praeliminaire vragen, die beantwoord dienen voor men aan socialistische praktijk toe is, op ongelooflijk lichtvaardige wijze zijn omgesprongen. Men kan in elk socialisatiegeschrift, waarmede wij hoofdzakelijk van socialistische zijde worden overstroomd, menige krasse uitdrukking vinden nopens de uitbuiting door het kapitaal, maar is zij bewezen? Wie de critiek op het Marxisme, op Marx' waarde- en meerwaardeleer geslaagd acht en de door de feiten allerwege bevestigde argumentatie naar eisch der logica aanvaardt, komt al spoedig onder den indruk, dat alle socialistische hervormingspogingen in collectivistische richting praematuur zijn, zoolang niet een tweede, gelukkiger Marx er in geslaagd is, de onjuistheid der ,burgerlijke" moderne waardeleer aan te toonen en daarvoor een andere, voor ieder onbevangene klemmende in de plaats te stellen, waaruit de principiëele juistheid der uitbuitingsthesis rechtstreeks zou voortvloeien. En nu hoede men zich voor één misverstand, dat het inzicht in dezen van meet af dreigt te beletten. Dezerzijds wordt het bestaan van uitbuiting onder het kapitalistisch productiesysteem (particuliere ondernemingen en ondernemers, private eigendom der productiemiddelen, vrije beroepskeus, zooveel mogelijk vrije concurentie en langs dezen weg tot stand komende prijzen, vrijheid van verbruik, privégenot van kapitaalrente. en pachtwaarde, om eenige hoofdzaken te noemen ${ }^{2}$ )) allerminst ontkend: er komen wantoestanden voor, waar de een profijt trekt uit de economische afhankelijkheid van den ander en den laatste in hoogeren zin onrecht toevoegt - men denke maar aan de misstanden van $\mathrm{zg}$. gedwongen winkelnering (koopdwang zou wijlen Mr. I. A. Levy zeggen) of aan die in de huisindustrie --, doch daarom gaat het in geenen deele! De principiëele vraag, die uitgevochten moet worden, en, let wel : theoretisch uitgevochten, is eenig en alleen deze : of alle kapitaalrente, àlle pachtwaarde, kortom àlle zg. arbeidsvrij inkomen door uitbuiting wordt verkregen, m. a. w. of er, voor zoover den oorsprong dier bronnen van inkomen aangaat, letterlijk niets goed aan is, omdat, naar het heet, daaraan het zweet en het bloed der arbeiders kleven. Dàt is de stelling van het socialisme, en juist deze wacht nog immer haar bewijs! De burgelijke economie heeft zich van haar geboorte tot wetenschap af, anderhalve eeuw lang,

2) Vgl. L. Pohle, „Kapitalismus und Sozialismus”, vooral blz. 5 v. 
wel alle denkbare moeite gegeven om. tot een algemeen geldige, causale verklaring te geraken van die veel omstreden verschijnselen; zij deed dat, als wetenschap, sine ira ac studio, om der waarheid wille en onbekommerd om welke politieke munt ook, die uit haar soluties zou kunnen worden geslagen. Na Marx' bewijs, dat ontdaan van alle dialectiek werkelijk niets bewijst, doet het socialisme alsof er, theoretisch, geen vuiltje aan de lucht is, trekt het de meeste stoute politieke conclusies uit praemissen, die niets meer dan even zoovele onbewezen stellingen zijn.

De productie om winst moet vervangen worden door productie in het algemeen belang. Dat klinkt zeker aantrekkelijk, en wanneer wij hooren, hoe allerlei schadelijke en minderwaardige goederen worden voortgebracht eenig en alleen omdat $\mathrm{zij}$ in bepaalde gevallen meer winst beloven dan nuttige zaken, dan zijn wij al half gewonnen. Maar toch! Zoodra wij dieper doordringen, zien wijdat in dezen de hoofdfout stellig niet bij de winstzieke productiewijze, waaronder wij nog goeddeels leven, gelegen is. De oorzaak schuilt bij de verkeerde behoeften, van welke een, natuurlijk even verkeerde stimulans uitgaat op de voortbrenging. Een betere mensch met uit ethisch oogpunt respectabẹle behoeften zal vanzelf de productie, die de vraag volgt, op hooger plan brengen. Misschien werpt men tegen, dat door het reclamewezen en op andere wijze ook van de aanbodzijde prikkels uitgaan, die soms afkeuring verdienen. Dit kan ten deele worden beaamd. Evenwel betreft de reclame voor een deel niet opwekken van nieuwe behoeften doch verandering in de verdeeling van een gegeven totaal-debiet. Maar ook voor zoover het initiatief in dezen uitgaat van de aanbodzijde, moet toch worden staande gehouden, dat het slagen en het misschien moreel afkeurenswaardige slagen in laatste instantie afhangt van den weerklank, dien de verleidingpogingen der ondernemers bij het consumentenpubliek vinden. Op den duur bepaalt dit en niemand anders de richting der productie. Productie van ,Schund" valt op de hoofden der verbruikers terug "). Daar-

$\left.{ }^{3}\right)$ In geheel anderen zin b.v. Franz Oppenheimer, Theorie der reinen und politischen Oekonomie, 4. Aufl., blz. 577 v., die in zijn requisitoir tegen "die Disharmonie der kapitalistischen Wirtschaft" te zeer de primairmotorische kracht der behoefte voorbijziet. De "maatschappij" aanvaardt geen geld, dat haar niet aanstaat, zij aanvaardt evenmin andere goederen tenzij met haar wil. Dáár, bij de behoefte, moet alle hervorming beginnen. Het is een quaestie van innerlijkheid. 
voor de Profit-zucht van het kapitalisme aansprakelijk stellen is grenzenloos oppervlakkig en het plaatsen van de dingen op hun kop. Laten nu de béhoeften, goed of verkeerd, dezelfde blijven, dan beteekent de productie onder het socialisme, dat alleen de goede bevredigen wil, een goed-bedoelde maar tevens de vrijheid verstikkende behoefteverzorging der gemeenschapsleden. Niet vànbinnen-uit doch van-buiten-af klinkt dan de stem, die zegt, welke productie door den beugel kan en welke niet. De grens tusschen het nuttige en schadelijke, tusschen het noodige en ontbeerlijke loopt, ook waar de hoofdrichting dezelfde is, bij ieder individu, bij elke als eenheid te denken groep weer anders. Op het terrein der behoeftevorming en der vraag toont zich de persoonlijkheid ongesluierd, van haar gunstige en haar min-gunstige zijde. Vrijheid en economische zelfverantwoordelijkheid vragen, behoudens de zelfverdediging der gemeenschap tegen aanranding, ruimte voor beide. En het is alleen de verheffing en veredeling van ons aller persoonlijkheid, die de eischen van vrije behoeftevorming en van een zedelijke idealen benaderende voortbrenging kunnen verzoenen. Geen collectief zedemeesterschap, geen Staat-catechiseermeester, doch de productie de weerspiegeling van een vraag, die op haar beurt de cultuurontwikkeling, den geestelijken en zedelijken vooruitgang van vrije menschen reflecteert. Dan zal kapitalisme, de gesmade winstmakerij, juist een waarborg worden tegen de productie van "Schund", zonder dat de vrijheid van ge- en verbruik, welker onschatbare waarde eerst in tijden van rantsoeneering ten deele tot ons doordringt, schade beloopt.

De huidige maatschappij is ernstig ziek. Het zou, na den wereldoorlog, die zooveel economische hulpbronnen, zooveel arbeidsvermogen voor minstens een menschenleeftijd verwoestte, wel een ongelooflijk wonder wezen, zoo dat anders ware. Een goed medicus tracht de ziekte, niet den patient uit de wereld te helpen. Het consequente socialisme doet echter het laatste. De maatschappij moet een andere worden, is reeds op weg een andere te worden, zoo wordt betoogd, met de uitgesproken of niet-uitgesproken bijgedachte, dat hervorming op den grondslag van het bestaande met het toedienen van palliatieven gelijk staat en de ziekte niet in haar oorsprong bestrijdt. Het kapitalisme is ongeneeslijk en onverbeterlijk, daarom: weg er mede!

Doch waar dan toch schuilt het uitbuitingselement, dat het kapitalisme constitueert ? Wordt alle kapitaalrente, om mij tot deze 
te bepalen, door uitbuiting verkregen? Het bewijs dient geleverd alvorens tot den banvlock en de daadwerkelijke uitbanning uit de privaat-huishoudelijke sfeer wordt overgegaan. Een paar gevallen uit het leven. lemand heeft door spaarzaam overleg jaar in jaar uit een deel van zijn inkomen (uit arbeid) afgezonderd. Hij laat een woonhuis bouwen - de sociaal-nuttige functie van zulk een gedraging leert geen tijd beter dan de onze - , dat hij verhuurt. Het netto-inkomen, dat na aftrek van alle kosten overblijft, is een zuivere kapitaalrente. Laat de huurprijs, de omstandigheden in aanmerking genomen, matig zijn. Waar is hier de uitbuiting ? Degeen die de rente verschaft is de huurder, hij zou het nadeel moeten ondervinden: nochtans krijgt hij, n'en déplaise het rentegenot van zijn verhuurder, volle waar voor zijn geld; hij zou vreemd opkijken wanneer hem werd voorgehouden, dat hij bezig is aan een ander een arbeidsvrij-inkomen te verschaffen dat op uitbuiting van hem, huurder, is gegrond. Of zouden de uitgebuiten de arbeiders zijn, die tot den bouw hebben samengewerkt? Stel, dat hun loonen het dubbele hadden bedragen: het gevolg zou geweest zijn, dat met cenzelfde kapitaal een naar rato kleiner huis zou zijn gebouwd, maar ook : dat met bouwen zóó lang zou worden gewacht, tot de huur van het kleinere huis even hoog zou zijn geworden als anders die van het grootere zou zijn geweest. Zoodat toch weer steeds hetgeen de huurder blijkens zijn toetreden toont over te hebben voor het genot van de woning de bron is, waaruit deze vorm van privé-inkomen vloeit. Een wijnhandelaar laat ettelijke okshoofden van zekeren jaargang liggen : zijn kapitaal, in dezen vorm belegd, gaat in waarde vooruit, de wijn draagt zijn eigen rente. De sociaal-democratische theoreticus moet nog geboren worden, die het uitbuitingskarakter van deze onvervalschte kapitaalrente onomstootelijk bewijst. Zoo kan men voortredeneeren. Tot de aardigste en pikantste passages uit von Böhm's standaardwerk over "Kapital und Kapitalzins" behoort wel die, waarin hij den "Zins im Sozialistenstaat" ") bespreekt. De staat, die alle productiemiddelen bezit, laat, aldus v. Böhm, alle leden der volksgemeenschap arbeid verrichten en betaalt hun daarvoor loon. Hij koopt het toekomstgoed-arbeid, - toekomstgoed omdat de arbeid gewaardeerd wordt naar de beteekenis van een product dat nog komen moet, - en verbiedt tegelijk aan de parti-

4) Positive Theorie des Kapitales, 3. Auflage, blz. 579 v. 
culieren om contracten met arbeiders af te sluiten. Een groep arbeiders bakt brood, een andere maakt een mijnschacht als begin eener productie die pas over 20 jaar genotsgoed oplevert, weer een andere groep legt een stuk bosch aan, dat na nog veel langer tijd rijp is om de grondstof hout te leveren. Hoe moeten die arbeiders nu betaald worden, hoe hoog moet hun daginkomen zijn, zal de socialistische staat de klip der uitbuiting omzeilen en zijn eigen bestaansgrond tegenover het kapitalisme, dat dood en begraven heet, handhaven ? Nu is het een bekend ervaringsfeit, dat arbeid, op een verder afgelegen doel gericht, een grooter product oplevert, dat, als de tijd dáár is, ceteris paribus ook een grooter waarde bezit. In v. Böhm's eigen woorden ${ }^{5}$ ): ,Während z. B. das Produkt, das ein Arbeiter in einem Tage beim Brotbacken erzeugt, vielleicht nur 2 fl. wert ist, mag ein Arbeiter bei der Aufforstungsarbeit in einem Tage vielleicht hundert Eichenschösslinge setzen, die, ohne weiteren Arbeitszusatz nach hundert Jahren zu kräftigen Eichenstämmen ausgereift, jeder $10 \mathrm{fl}$,, also zusammen 1000 fl. wert sein mögen." En nu de vraag: „Wie viel kann und soll nun der Sozialistenstaat jenen Arbeitern, deren Arbeit er auf technisch ergiebigere ferne Produktionsziele richtet, an Lohn auszahlen? Den ganzen Wert ihres künftigen Produkts? Also den Aufforstungarbeitern einen Taglohn von 1000 fl. ? Unmöglich! Das wäre eine schreiende Ungerechtigkeit gegen die Arbeiter der anderen Branchen." Liet men de arbeiders vrij, dan zou ieder dezen boscharbeid gaan verrichten en niemand zou meer brood willen bakken: ,das Land würde wieder in einen Urwald verwandelt, und die Gegenwart mit ihren drängenden Bedürfnissen bliebe unversorgt." Laat men den arbeiders niet de keus van het werk, en betaalt men een minderheid f 1000 per dag, terwijl de anderen f 2 á f 3 ontvangen, dan voert men, aldus v. Böhm, een nieuwe geldaristocratie in optima forma in, „nur dass sich diese nicht, wie heute, auf Besitz, sondern noch schlimmer auf Gunst und Protektion stützt." 'Men stelle zich gerust: dit alles gebeurt niet in den socialistenstaat, on de eenvoudige reden, clat ook hij wel, door de natuur der dingen zelve, gedwongen is zich als een rasechte kapitalist te gedragen. v. Böhm's conclusie is onaanvechtbaar, wanneer hij zegt: „Zahlt meñ aber — und das ist das einzig Mögliche - auch den Aufforstungsarbeitern geradc.

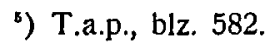


so wie den Bäckern nur $2 \mathrm{fl}$. täglich, dann begeht man ihnèn gegenüber dieselbe ,Ausbcutung", die heute die kapitalistischen Unternehmer ausüben. Man bringt-im Kaufe der Zukunftsware Arbeit ein Agio für Gegenwartsgüter in Rechnung, und fertigt den Arbeiter für ein Zukunftsprodukt von 1000. fl. mit einem gegenwärtigen Lohn von $2 \mathrm{fl}$. ab, entsprechend dem heutigen Werte der gepflanzten Schösslinge. Dèn Mehrwert aber; den diese im Laufe ihrer Ausreifung zu schlagfähigen Eichenstämmen ansetzen, schiebt die sozialistische Gemeinwirtschaft als echten Zins in die Tasche." Mij dunkt, hierop mag toch wel eens het volle licht vallen. Het merkwaardige is, dat dit punt van socialistische zijde wordt toegegeven, maar laat men dan ook eerlijk zijn, en erkennen, uitgaande van de stelling dat alle rente aan uitbuiting haar aanzijn ontleent, dat onder het socialisme de rente en de uitbuiting in stand blijven en zich slechts verplaatsen van de particuliere kapitalisten naar den monopolist-kapitalist, die dan de gemeenschap zijn zal. Ook in den socialistischen staat zal kapitaalinstandhouding en kapitaalvorming brood- en broodnoodig zijn. Particuliere spaarders mogen daarvoor niet meer zorgen, omdat het eenige object, dat hun, voor besparing zal resten, genotsgoed is, met uitsluiting van den renteprikkel, die thans zoo talloos velen hun vertering doet uitstellen. Die zorg voor het kapitaal, als onmisbaar hulpmiddel der productie, is onder het socialisme te meer noodig, waar dit aan den eenen kant een vermeerderde algemeene welvaart in uitzicht stelt en aan den anderen kant in principe het bevolkingsbezwaar, in heden of toekomst, loochent. De vermeerderde productie zal een steeds wassende bevolking tegenover zich vinden, waar immers niet in een te hoog bevolkingscijfer, doch in de kapitalistische productiewijze de oorzaak der armoede en bekrompen levensomstandigheden van de massa wordt gezocht. Dat het bevolkingsbezwaar echter het socialisme zijn triumf zal betwisten en aan de inlossing der welvaartsbelofte den voet zal dwarszetten, moet ieder onbevooroordeelde duidelijk worden, zoodra hij bedenkt, dat de economische zelfverantwoordelijkheid, die een der kenmerken is van het huidig systeem, plaats maakt voor een welvaartsgarantie door de gemeenschap ten behoeve van ieder, die werken kan en werken wil, en dat de op natuurlijke en economische factoren gebaseerde wet der afnemende meer-opbrengsten (law of diminishing returns), die met de historische categorie 
van het kapitalisme niets heeft te maken daar zij van algemeene geldigheid is, nog nimmer op afdoende wijze door de socialistische doctrine is weerlegd. Het eenige wat men kan doen is hopen, dat wetenschappelijke en technische vooruitgang voornoemde wet in haar werking telkens weer zal tegenwerken en met een batig saldo overheerschen, doch meer dan een hoop is dat niet, vooral zoo men wil, dat de aldus gewonnen leveinsrumte voldoende zal zijn en bovendien tijdig zal intrccen. Kan met betrekking tot mogelijke vindingen, die ons wat minder afhankelijk van het begrensde aardoppervlak moeten maken, het socialisme ons een betere kans verschaffen dan thans bestaat? Alleen dán zou het voegen tegenover Malthusiaansche bezwaren een hooge borst te zetten. Het vervaardigen van stikstof uit de luclit is een grandiooze vinding... onder het kapitalisme, onder den drang van een, naar het heet, kapitalistischen oorlog, tot stand gebracht. Maar, wil ik vragen, staat het, met allen eerbied voor dezen technischen vooruitgang, vast, dat de menschheid de uitputting van de salpeterlagen in Chili met gekruiste armen kan tegemoet zien ? Hoe staat het met de economische vooruitzichten van de langs synthetischen weg gewonnen stikstof ? Steunde die oorlogsproductie niet bijgeval op oorlogsprijzen ? Dreigt niet, als Chili uitgeput raakt, een economische stikstofnood, al is de techniek menschelijkerwijs gesproken tot volkomenheid gebracht? ${ }^{6}$ ) Techniek, het is haar recht, vraagt niet naar kosten. De menschheid, voor haar doel, des te meer. Wat de laboratoria wrochten, is lang niet altijd aanwendbaar in het groot. En ook wanneer zulks in een gunstig geval wèl mogelijk is, blijft nog de kostenkwestie spoken, en steekt Malthus, zoo de technische vooruitgang niet tevens kostenbesparing beteekent, weer dadelijk zijn neus om den hoek van de deur ! ${ }^{7}$ )

Ik keer tot de kapitaalvorming in een socialistische gemeen-

") Vgl. „De stikstof-nood en de middelen tot zijne bestrijding” door prof. dr. F. M. Jaeger. Deze schrijver, hoewel erkennende dat het vraagstuk technisch geheel is opgelost, waarschuwt tegen ongemotiveerd optimisme voor wat de kostenzijde der quaestie betreft.

$\left.{ }^{7}\right)$ Men raadplege o.a. de bekende in ons land in 1917 door den Berlijnschen hoogleerar Dr. Julius Wolf gehouden rede over „Nahrungsspielraum und Menschenzahl", waarin hij op beknopte, systematische wijze de wetten bespreekt, die den vooruitgang aan steeds knellender banden leggen. $\mathrm{Bij}$ hem vergeleken wordt zelfs Mathus een optimist ! 
schap terug. Voor verreweg het grootste gedeelte wordt thans het kapitaal gereconstrueerd en vergroot uit drie inkomstentakken: de kapitaalrente, de pachtwaarde en de ondememerswinst. Bij de laatste denken we in de eerste plaats aan de dividenden der naamlooze vennootschappen, voor zoover zij den heerschenden rentestand te bovengaan. En nu komt August Müller in zijn geschrift "Sozialisiering oder Sozialismus ?" ") met prijzenswaardige eerlijkheid de volgende cijfers aandragen, die R. Kuyper in zijn rede over "Socialisme en Socialisatie" overneemt: Voor den oórlog bedroeg het totaal-inkomen in Duitschland \pm 40 milliard mark, bij een maatschappelijk vermogen van \pm 300 milliard. Van die 40 milliard gingen naar schatting 15 millard heen aan de kapitalisten inclusief de grondeigenaars. De resteerende 25 milliard vormde het inkomen van ,de eigenlijke producenten". Uitdrukkelijk zegt Müller, dat het een foutieve meening zou wezen, dat een gesocialiseerde maatschappij de meerwaarde in haar geheel (15. milliard) ter beschikking van de volksgenooten zou stellen. Want wat gebeurt daar thans mede ? Müller rekent uit dat 8 à 10 milliard wordt aangewend voor afschrijving, nieuwe installaties, nieuwe fabrieken enz. enz. Van de overblijvende 5 millard wordt de helft in buitenlandsche ondernemingen aangewend en volgt dus ook de kapitaalbestemming. Er bleef dus in Duitschland vlak voor den oorlog circa $2 \frac{1}{2}$ milliard over, waarvan de kapitalistenklasse min of meer weelderig leefde. Alleen dit laatste bedrag zou, bij socialisatie, voor verdeeling onder de arbeiders beschikbaar komen en hun jaarloon per hoofd met ongeveer 100 mark doen stijgen. De arbeiders, die eerst ${ }^{23} / \infty$ van het maatschappelijk inkomen ontvingen, krijgen dan ${ }^{s n} / \mathrm{sn}$, m.a.w. zij gaan $10 \%$ vooruit. ${ }^{\circ}$ ) Kuyper rekent eenigszins anders: „Aannemende, dat er 10 milliard per jaar voor uitbreiding en verbetering van de voortbrenging binnenslands en voor ook in het socialisme noodige belastinguitgaven noodig is en $5^{\prime}$ milliard aan weeldevertering en buitenlandsche kapitaalbelegging kan vervallen, komt men door de beperking en de gedeeltelijk andere aanwending van het vroegére arbeidslooze

$\left.{ }^{8}\right)$ „Eine kritische Betrachtung über Revolutionsideale” von Dr. August Müller, Staatssekretär a. D., Berlin, Ullstein \& Co., 1919, blz. 78 v.

") Prof. J. D. J. Aengenent, in zijn rede „Het Bedrijfsradenstelsel verwezenlijkt”, blz. 22, zegt in dit verband: „Dergelijke cijfers zijn eenvoudig overbluffend. En zou het nu niet gewenscht zijn, dat zij veel meer gepubliceerd werden ...?" 
inkomen in een socialistische maatschappij tot een algemeene welvaartsvermeerdering van 20 percent." $\left({ }^{23} / 10:{ }^{30} / 10=100: 120\right)$. Dit laatste is sterk geflatteerd; hoewel ook bij deze veel te gunstige cijfers de zegswijs : tant de bruit pour une ommelette" niet geheel misplaatst zou zijn. Want de heer Kuyper rekent bij het voor de arbeiders beschikbaar komend deel van het maatschappelijk inkomen maar liefst de $2 \frac{1}{2}$ milliard kapitaal, die jaarlijks in het buitenland belegging zocht, en laat dus, alleen ondat het hier buitenlandsche belegging geldt, de vertering met dit bedrag ten koste van de kapitaalvorming aanzwellen. Alsof het er voor den kapitaalrijkdom van een land principieel iets toe doet, waar dat kapitaal toevallig zijn emplooi heeft gevonden, binnen of buiten de grenzen! Dat is wel sterk nationalistisch gedacht, van een zijde, waarvan men zulks niet in de eerste plaats zou verwachten. In het systeem van dezen publicist zou dus de gesocialiseerde maatschappij met minder kapitaal produceeren dan de kapitalistische, en wel met minder naar mate de beleggingsgewoonten onder het kapitalisme toevallig zich meer naar het buitenland hadden georiënteerd. Men moge aldus het onder de arbeiders te verdeelen inkomstenbedrag wat flatteeren, de opvoering lijkt kunstmatig en te gaan ten koste van een normalen totaal-inkomen-aanwas, zooals deze onder het kapitalisme, dank zij besparing en belegging, bestond ${ }^{10}$ ).

Laten wij dus, ter wille van het noodzakelijk op peil houden en liefst nog vermeerderen van de productie aannemen, dat alleen de luxe-verbetering der kapitalisten-klasse een einde neemt en dat in den vorm van nuttige zaken het inkomen der „eigenlijke producenten" een weinig wordt verhoogd. Wat doet de socialistische gemeenschap nu anders dan, bchoudens dat kleine deel dat zeker geen zoden aan den dijk zet, evenzeer de arbeiders uitbuiten, hun „Recht auf den vollen Arbeitsertrag" verkorten als voorheen aan het kapitalisme als onduldbare praktijk en eeuwige schande werd

$\left.{ }^{10}\right)$ Veel juister dan ook August Müller, t.a.p., blz. 80: „Da die Exporte von Kapital ins Ausland genau so zu bewerten sind wie die für Abschreibungen und Neuanlagen verwandten, so darf also eine Gesellschaft, die durch Sozialisierungsmassnahmen den Verteilungsprozess ändert, mit annähernd 2 Milliarden rechnen, die Kapitalisten und Rentenbeziehern entzogen und den breiten Volksmassen zugeführt werden könnten." Men vgl. de belangrijke beschouwingen van prof. mr. 'dr. Ant. van Gijn: Wat zal de naaste Tijd brengen? blz. 24/25, over gelijk opdeelen of meer gelijkmaken der inkomens. 
verweten? De uitbuiting, die met het kapitalisme verdwijnen zou, in eere hersteld! De onrechtvaardige inkomstenverdeeling, waarop immer het zwaarste geschut uit het socialistische kamp werd gericht en voor welker ter-zijde-stelling des noods het productiebelang, van den winstprikkel beroofd, een veer zou mogen laten, bestendigd! Wanneer om dit poover resultaat de maatschappij tot in haar grondslagen moest worden herzien en aan het socialistisch experiment onderworpen: de berg zou een belachelijk muisje hebben gebaard. Geen wonder dan ook, dat in den laatsten tijd, toen de socialisatie-leus aan kracht ging winnen, het zwaartepunt der argumentatie naar de productiezijde werd verlegd en de overtuiging onder de aanhangers veldwon, dat niet de afschaffing van het arbeidsvrij inkomen, doch de verhooging der arbeidsproductiviteit, welke van socialisatie wordt verwacht, de meerdere welvaart zal moeten brengen. Maar toch, dat rente- en pachtwaardegenot door de in de plaats van de uitbuitende kapitalisten getreden socialistische gemeenschap blijft een wonderlijke contradictie. Ook hier heeft v. Böhm rake opmerkingen. Nadat hij, gelijk wij zagen, gezegd heeft, dat voortaan de gemeenschap de meerwaarde als echte rente in den zak steekt, vervolgt hij: „Vielleicht, wahrscheinlich sogar, um ihn nicht in der Tasche $z u$ behalten, sondern zu einer allgemeinen Aufbesserung der Lohnquote der Volksarbeiter zu verwenden. Aber eine solche nachträgliche gemeinnützige Widmung des eingestrichenen Zinses ändert nichts an der Tatsache, dass der Zins als Zins eingestrichen wurde. Der Sozialistenstaat handelt da nur ähnlich, wie ein heutiger Kapitalist handeln würde, der aus eingestrichenem Mehrwert ein Vermögen von Millionen aufhäuft, und über dieses dann zu gemeinnützigen Zwecken verfügt. Man kann über erworbenen Lohn egoistisch oder altruistisch verfügen, und man kann über erworbenen Zins egoistisch oder altruistisch verfügen : aber so wenig jemand die Behauptung wird wagen wollen, dass ein Arbeitslohn dadurch, dass man ihn egoistisch verwendet, zum Zinse wird, ebenso wenig wird man auch behaupten dürten, dass ein erworbener Zins dadurçh, dass man über ihn altruistisch verfügt, nachträglich seine Natur ändert und vielleicht in Arbeitslohn umschlägt!" Het is een niet te ontkomen consequentie, dat de beweerde vicieuse oorsprong van het arbeidsvrij inkomen ook kleeft aan de meerwaarde, die de gemeenschap tot zich neemt en nemen moct en dat de besteding, voor het overgrocte deel tot kapitaalreconstructie en -vergrooting en in 
zoover in niets verschillend van den huidigen toestand, dat vitium originis niet kan schoonwasschen. Ook is het zondeling, in den gedächtengang dien wij hier bestrijden, dat het uit zou zijn met de belegging van kapitaal in buitenlands gevestigde bedrijven. Wanneer de misvatting van den heer Kuyper, dat het jaarlijks uit het inkomen thans daarvoor afgezonderde kapitaal onder het socialisme voor verhooging van het arbeidsinkomen zou moeten worden aangewend, wordt vermeden in dier voege, dat dit kapitaal niet wordt opgeteerd doch in de binnenlandsche, gesocialiseerde bedrijven gestoken, dan nòg is er achteruitgang in productiviteit, vergeleken bij thans. Immers dat nu landen worden gevonden, die ondanks het grootere risico een deel van het gevormde kapitaal in buitenlandsche ondernemingen beleggen, welke landen wij de kapitaal-actieve zouden kunnen noemen, wijst er op, dat met zulk een belegging meer voordeel is te behalen dan op de relatief nauwe kapitaalmarkt in het binnenland. Dat nu is niet alleen voordeelig voor de betrokken kapitalisten, maar zeer zeker ook voor de volksgemeenschap, die haar totaal-inkomen vergroot ziet, en niet minder voor de kapitaal-passieve landen en streken, die hun relatief kapitaalgebrek wat verminderd zien en met buitenlandsche hulp economische welvaartbronnen kunnen aanboren, welke anders in het geheel niet zouden worden benut of althans veel minder ruim zouden vloeien. Het is merkwaardig, hoe de afkeer van kapitalistische expansie en het op zichzelf te waardeeren streven om economische botsing op internationaal gebied te voorkomen, toch weer voert tot een nationalistische kapitaal-politiek, maar nu in den vorm van een gesloten kapitaal-huishouding, met opoffering van dat stuk algemeene en bijzondere welvaart, hetwelk uit de mogelijkheid om over de geheele wereld het meest rendabele kapitaal-emplooi op te zoeken, vanzelf voortvloeit. De vrijhandel, die ook in het internationale kapitalisme, in de politiek der kapitaalactieve en kapitaal-passieve landen tot uiting komt, verkeert, gewild of ongewild, bij het beletten van buitenlandsche kapitaalbelegging en bij het principieel niet-treden te dezen door de gesocialiseerde gemeenschap in de voetstappen van de particuliere kapitaalbeleggers, in protectie met alle gevolgen van verzuimde welvaart, die terugdringing van het internationaal verkeer medebrengt. Verschillende schrijvers over socialisatie, en nu ook weer het in menig opzicht merkwaarige socialisatie-rapport dat onlangs in „Het Volk" verscheen, toonen een open oog te hebben voor het 
onschatbare belang, dat de heele menschheid heeft bij internationale arbeidsverdeeling. Beseft men dan niet dat deze alleen bestaan en bloeien kan, wanneer het kapitaal vrij wordt gelaten althans in dien zin, dat het niet gebonden is aan de van economisch standpunt volmaakte willekeurige grenzen der politieke complexen, die door de staten met hun koloniën worden gevormd ? Is de beschikbaarstelling van inkomen waaruit tot dusver in het buitenland te beleggen kapitaal gevormd werd, ten behoeve van de arbeiders een politiek van algemeene verarming, ook een politiek, die deze kapitaalvorming wèl zou willen handhaven doch voortaan alleen ten behoeve van de binnenlandsche productie (de koloniën inbegrepen), komt in botsing met het ook door een socialistische gemeenschap niet straffeloos, d.i. niet zonder onnoodig welvaartsoffer, te verzaken economisch beginsel, volgens hetwelk met de beperkte beschikbare middelen, met de tegenover de menschelijke behoeften immer schaarsche productiefactoren, het grootst mogelijke welvaarteffect moet worden nagestreefd. Socialisatie wil verspilling op het gebied der voortbrenging, die zij, tot zekere hoogte terecht, aan het huidige systeem verwijt, voorkomen : hier echter zou zij de productiviteitsvoordeelen van het internationale kapitalisme om politieke redenen, die vierkant tegen de economische welke zij zelve voorstaat indruischen, zoo maar prijs geven ?

v. Böhm merkt verder nog op, dat door een gelijkmatige verdeeling van de door den socialistischen staat betrokken rente geenszins dezelfde economische toestand zou ontstaan als wanneer die rente niet was binnengekomen : ,... in der Verteilung bekommen ihn ganz andere Leute als jene, an deren Arbeit und Produkt er verdient wurde. Dem Aufforstungsarbeiter wird vom Werte seines künftigen Produktes von 1000 fl. ein Betrag von $998 \mathrm{fl}$. als Zins abgezogen. Wird nun durch die Austeilung aller so gewonnenen Zinsbeträge der.Durchschnittstaglohn vielleicht von zwei auf drei Gulden erhöht ${ }^{13}$ ), so bekommt jener von 998 abgezogenen Gulden einen einzigen zurück, und die übrigen $997 \mathrm{fl}$. bekommen andere Leute, und zwar ganz wie heute, nicht aus dem Titel der Arbeit, sondern aus dem Titel des Eigentums, beziehungsweise des Miteigentums." Hij betoogt dan verder, m.i. volkomen juist, dat

11) De burgerlijke econoom is hier in zijn voorbeeld met een verhooging van $50 \%$ nog heel wat royaler dan de heer Kuyper, die slechts $\pm 20 \%$ uit Duitsche cijfers durft in uitzicht stellen en daarbij, naar wij zagen, nog te ver gaat. 
de lieden, die met bakkersarbeid een dagproduct van f 2 leveren en dus een loon van $\mathrm{f} 2$ verdienen, den $3 e n$ gulden niet als arbeiders doch als mede-eigenaars aan het nationale vermogen zich zien uitbetaald. De staat kan dien bijslag verleenen, omdat hij als eenig bezitter van de productiemiddelen, als kapitalist in monopoliepositie, tegenover de producenten van meer- of minder verwijderd toekomstgoed, de volle macht van zijn eigendomsrecht doet gelden, zoodat zij zich een reductie tot de "contante waarde" moeten laten welgevallen: „Im Sozialistenstaate wird daher geradeso wie in der kapitalistischen Gesellschaft der Zins vom Eigentümer der gegenwärtigen Güter an jenen Arbeitern verdient, die durch ihre Arbeit erst ein künftiges Produkt schaffen: der Unterschied besteht nur darin, dass in der kapitalistischen Gesellschaft das Eigentum ungleich verteilt ist, und der Zins an wenige Eigentümer in grossen Quoten fällt, während in der sozialistischen Gesellschaft Alle Miteigentümer zu gleichem Anteil sind und Alle eine gleiche kleine Quote vom Gesamtzins einstreichen." Inderdaad, waar is hier, van uitbuitingsstandpunt, het principiëele verschil ?

Maar de groote hefboom der socialisatie, die uitbuitingsleer zelve ? Treden we deze nog een oogenblik nader. Want, al valt hier voor de ingewijden in de economische leerstukken weinig nieuws te vermelden, het is nuttig en noodig, dat de gansche theoretische voosheid dier leer, waaraan zulk een fel requisitoir tegen de bestaande productiewijze en tegelijk zulke vergaande sociaal-politieke gevolgtrekkingen worden vastgeknoopt, in breeden kring duidelijk wordt. Het heeft er veel van, of het socialisme, naar mate het door een dikwijls gerechtvaardigde critiek op bestaande misstanden als sociaal-politieke partij in kracht, blijkens de stembuscijfers, is toegenomen, minder is gaan hechten aan de aanwezigheid van juiste, theoretische grondslagen, die toch, te midden van de warreling van opportunistische inzichten en nimmer algemeen overtuigende billijkheidsoverwegingen, alléén de noodige vastheid aan program en leiding zouden kunnen verschaffen. Het is de groote verdienste van Marx, dat hij althans een ernstige poging deed. $Z_{\mathrm{ij}}$ faalde, en met haar faalde het zich nog zoo gaarne wetenschappelijk noemende socialisme. $\mathrm{Na}$ de weerlegging van de Marxistische waardeleer is er van strenge socialistische wetenschap geen sprake meer. Men heeft genoeg aan propaganda en politiek. Ondanks alle uitwendig succes beteekent dit innerlijke achteruitgang. 
Het deel van het Marxistisch leergebouw, dat ik op het oog heb, is van eenvoudige constructie, te eenvoudig en daardoor in strijd met de ingewikkelde werkelijkheid. Marx leerde - en hij sloot zich in dezen bij enkele klassieke Engelsche economen, vooral Ricardo, aan, die nimmer van dit gebruik van hun leerstellingen hadden gedroomd - , dat beginsel en maat van alle ruilwaarde de menschelijke arbeid is. Niet de concrete arbeid, die is aangewend, maar een maatschappelijk gemiddelde. En ook niet de concrete, arbeid in zijn toevallige verschijning, b.v. als spinatbeid of meubelarbeid, maar abstracte arbeid. Alle gebruikswaarden, alle „waren" laten zich hierin oplossen. Wanneer-nu alle ruilwaarde haar beginsel en haar maat vindt in den gemiddelden noodwendigen maatschappelijken arbeidstijd, dan - en dit is de specifiek Marxistische vondst -- geldt zulks ook van de waarde van den arbeid zelven, d.i. voor de loonvorming onder het kapitalisme. De arbeidstijd, noodig voor de reproductie van de arbeidskracht, vormt den maatstaf der loonbepaling. Deze arbeidtijd is korter dan de tijd, dien de arbeider zelf werkt, en wordt zẹlfs, bij den vooruigang der techniek, nog voortdurend ingekort : het gevolg is de noodzakelijkheid, krachtens de arbeidswaardewet zelve, van meer-waarde, d.i. een waardesurplus der arbeidsopbrengst boven hetgeen de arbeid op grond van voornoemde wet waard is en dus aan loon kan bedingen. Het kapitalisme; dat scheiding gebracht heeft tusschen den werker en de pruductiemiddelen, maakt den eerste afhankelijk van den bezitter der laatste, die het gebruik alleen toestaat in den rechtsvorm van het loonstelsel. Het is de economische noodzakelijkheid, de afhankelijheid van den onder het kapitalisme tot proletariër geworden handwerker, die den kapitalist de beschikking geeft over het tegen loon afgekochte product en hem de meerwaarde verzekert. Men ziet, alles sluit als een bus, maar ten slotte hangt de keten van het gansche betoog aan één eindschakel, waarvan nu de deugdelijkheid moet worden nagegaan. Knapt hij af, dan ligt alles, en wacht de uitbuitingstheorie op nieuw bewijs, van meet af. Hij knapt niet meer af, om de eenvoudige reden, dat dit reeds een halve ceuw geleden plaats vond, toen ongeveer gelijktijdig op drie plaatsen van den aardbol de moderne waardeleer haar kaartje pousseerde. Zij leverde de meest eclatante positieve, opbouwende critiek tegen het eenzijdige arbeidswaardeprincipe, en sedert heeft ook de negatieve critiek; die den leeuw in zijn hoi opzocht en het spinneweb van dialectisch 
raisonniement, waarachter hij zich veilig achtte, verscheurde, niet gerust.

Het eerst viel wel op, dat Marx zijn onderzoek beperkt had tot waren, dat zijn : voor de markt vervaardigde arbeidsproducten. Op zoek naar het gemeenschappelijk element, het tertium comparationis, waardoor de ongelijksoortige goederen onderling vergelijkbaar worden, hetgeen volgens Marx voor het ontstaan der ruilmogelijkheid, die op gelijkstelling berust, noodzakelijk is, valt het dán niet moeilijk den arbeid, tevoren er in gelegd, als hèt ge meenschappelijke er weer uit te halen. Doch het is onmiddellijk duidelijk, dat het niet aangaat het veld van onderzoek kunstmati!s te beperken tot ,waren" en dan te doen, alsof het aldus gevonderl resultaat geldigheid zou hebben voor álle waardeverschijnselen, ook buiten het terrein, dat door waren wordt ingenomen. Een waardeleer verklaart alles of niets. $\mathrm{Er}$ is geen middenweg mogelijk. Maar bovendien! Is het waar, dat de ruil op een vergelijking, op een gelijkstelling van' hoeveelheden berust? Het is reeds lan!r vóór Marx beweerd, o.a. door de oude physiocratische school. Mercier de la Rivière, de bekende physiocraat, schrijft in zijn boeis over "L'ordre naturel des sociétés politiques" ${ }^{12}$ ) o.a. : „Le commerce est un échange de valeurs pour valeurs égales .... Ainsi, après une telle opération, chacum d'eux n'est ni plus riche ni plus pauvre qu'il n'était", waarop hij in flagrante tegenspraak met het voorgaande de woorden doet volgen: „quoiqu'il ait en sa possesion une chose qui lui convient mieux que celle qu'il avait auparavant." Men voelt instinctief, dat het met die ,valeur pour valeur égale" ietwat eigenaardig geschapen staat, want waartoe al dia omslag van ruilen, die veelal nog kosten meebrengt bovendien, wanneer niet meer "waarde" wordt ontvangen dan afgestaan? De moderne waardeleer zegt dan ook, dat juist ongelijkheid van waarde voor de ruilende partijen het principe van den ruil uitmakkt, en dat deze slechts mogelijk is, wanneer zij dezelfde zaak verschillend, d.i. tegengesteld schatten, n.l. ieder de eigen zaak lager dan de in te ruilen vreemde zaak. Dat is heel iets anders dau de beweerde gelijkstelling. Maar nu verder: laat Marx ook hier gelijk hebben, en laten ruil en ruilwaarde slechts mogelijk zijn doc de goederen te brengen op denzelfden noemer: moet deze dau noodwendig de gemiddelde maatschappelijke arbeidstijd zijn ? Is

\footnotetext{
iz) Uitgaaf van Eugène Daire, Deuxième Partie, blz. 544.
} 
deze het éénig-gemeenschappelijke ? Volkomen terecht wijst $\mathrm{v}$. Böhm er op, dat de goederen, die geruild worden, b.v. óók gemeen hebben: dat $z$ ij een stuk natuur belichamen als dragers van natuurkracht; dat zij als gebruikswaarden in staat zijn -of, wat economisch hetzelfde is, in staat geacht worden, - menschelijke behoeften te bevredigen; dat zij schaarsch zijn in verhouding tot de behoefte, die gekend wordt wanneer geen prijs de vraag zou besnoeien en zij dus te geef waren; dat zij voorwerp zijn van vraag. en aanbod. Waarom moet nu juist de arbeid of de arbeidstijd, die met de voortbrenging is gemoeid, het waardegevend moment vestigen? Zoo uit jets de bevangenheid van Marx' oordeel blijkt, dan $_{a}$ is het wel zijn niet gemotiveerde keus van den arbeid uit de andere mogelijkheden, die hij eenvoudig negeert, en waardoor zijn geheele bewijsvoering willekeurig wordt, dat is dienstbaar gemaakt aan een vooraf gesteld doel. Hetgeen natuurlijk goede trouw allerminst uitsluit.

Er blijft nog één vernietigend argument voor korte bespreking over: de bekende tegenstrijdigheid tusschen het $3 \mathrm{e}$ en het le boek van Marx' werk over „Das Kapital". Marx neemt in zijn eerste boek aan, dat het kapitaal uit twee deelen bestaat, een constant en een variabel deel; het laatste is het loonfonds, waarmede de meerwaarde wordt verkregen, terwijl het constante bestanddeel alle overig kapitaal is, dat, zonder waardesurplus, alleen in de productie zichzelf in stand houdt: vandaar de qualificatie ,constant". De onderscheiding, die zeker van belang is, mag allerminst worden verward met die van vast en vlottend kapitaal. Marx zegt nu verder, volkomen juist, dat de organische samenstelling van het totale kapitaal, d.i. de verhouding van het constante en variabele bestandeel, in de verschillende bedrijven verschillend is: in het eene bedrijf wordt veel constant en weinig variabel kapitaal gebruikt, in het andere is het juist anderom. Maar steeds wordt alleen met en door het variabele deel, dat immers den-arbeid tewerkstelt, de meerwaarde verkregen, dat is de uitbuiting voltrokken. Laat de uitbuitingsgraad zich door een rentestand van b.v. $5 \%$ manifesteeren, dan is het alweer begrijpelijk, dat die $5 \%$ de verhouding aangeeft tot het variabele deel, en niet tot het gehecle kapitaal, het constante dus inbegrepen. Bedrijven met een even groot variabel kapitaal, waarin de arbeidstijd gelijk is en de arbeid uit een oogpunt van opleiding gelijkwaardig, zullen even veel meerwaarde voortbrengen, onverschillig hoe overigens 
het constante kapitaal daarin vertegenwoordigd is. Bij gelijke rente in relatie tot het variabele deel, wordt dus de rente ongelijk, wanneer $z$ ij wordt uitgedrukt in percenten van het geheele in de ondernemingen gestoken kapitaal, zoodra, en dat is de regel, de verhouding tusschen de variabele en constante bestanddeelen, de organische samenstelling, verschilt. $M$. a. w. : een uniforme rentestand en de tendens om, bij verbroken evenwicht, langs den weg der concurrentie tot uniformiteit terug te keeren, zijn in deze redeneering, die van de arbeidswaarde is doortrokken, onmogelijkheden. Evenwel : de werkelijkheid geeft deze tendens wel degelijk te zien. Wanneer in het eene bedrijf het kapitaal rijker vruchit afwerpt dan in het andere, worden ondernemingen der laatştbedoelde branche ingekrompen en geliquideerd, komen er in den groote winst belovenden tak nieuwe bij en breiden bestaande zich uit : dit zal zoo lang duren tot nivelleering van kapitaal-rendement intreedt of feitelijke belemmeningen aan volkomen aanpassing in den weg treden. Marx, die hiermede rekening houdt, in zijn $3 \mathrm{e}$ boek, waar hij in zijn eigenaardige terminologie van ,Durchschnittprofitrate" gewaagt, geeft dit toe, erkent de nivelleering der winsten en haar neiging om tot een uniformen rentestand te graviteeren, maar offert aldus de arbeidswaardeleer op. Want het zal duidelijk zijn, dat die uniforme rentestand een verhouding uitdrukt tot het hecle kapitaal, onverschillig de quota constant en variabel kapitaal daarin aanwezig, terwijl de arbeidswaarde alleen ten aanzien van het variabele bestanddeel zoodanigen rentestand zou kunnen meebrengen. Om het duidelijke voorbeeld van v. Böhm ${ }^{13}$ ) onveranderd over te nemen. Een juwelier en een schoenmaker hebben voor gelijk loon een even groot aantal arbeiders (10) in dienst, gebruiken dus eenzelfde variabel kapitaal, stel $\mathrm{f} 5000$. Zij laten hun personeel even lang werken. Uit den aard der zaak is er ten aanzien van het constant kapitaal groot verschil. De juwelier heeft aan grondstoffen enz. een bedrag van $f$ 195.000, de schoenmaker van $f 5000$ in zijn zaak gestoken. De kapitalen zijn dus $f 200.000$ en $f 10.000$. Volgens het arbeidswaardebeginsel voegen de arbeiders in beide producties gedurende een jaar eenzelfde waarde toe aan de grondstoffen, die $z \mathrm{ij}$ veredelen tot eindproducten, stel $f$ 10000.- D. Dit beteekent, waar aan loonen

$\left.{ }^{23}\right)$ v. Böhm behandelt dit punt in zijn "Geschichte u. Kritik”, blz. 536 v. Het in den tekst weergegeven voorbeeld vindt men echter op blz. $491 \mathrm{v}$. bij gelegenheid van Böhm's critiek op 'Rodbertus' uitbuitingstheorie. 
gedurende het jaar $f 5000$ is uitgegeven, een meerwaarde van f 5000 , d. i. over het variabele kapitaal in beide ondernemingen $100 \%$, maar over het gehecle kapitaal in de juwelierszaak $2 \frac{1}{2} \%$ en in de schoenmakerszaak $50 \%$. Dit is een onhoudbare toestand. De leer van de „Durchschnittprofitrate" moet uitkomst brengen. In beide bedrijven moet „het" kapitaal ongeveer een gelijke rente afwerpen. Hoe? De juweliersbranche wordt ingekrompen, het aanbod van gouden en zilveren werken vermindert, zij. stijgen in prijs; van den anderen kant komen er in de groot voordeel gevende schoenmakerij veel nieuwe zaken bij en breidenvde bestaande zich uit: de prijzen voor allerlei schoenwerk dalen bij sterk toenemend aanbod. Dit gaat door tot de waardetoevoeging aan de grondstof door de tien arbeiders in het juweliersvak dank $z$ ij de verbeterde markt van $f 10.000$ gestegen is tot $f \mathbf{1 5 . 0 0 0}$ en die van de tien arbeiders in het schoenmakersbedrijf van $f \mathbf{1 0 . 0 0 0}$ door de achteruitgaande markt gedaald is tot $f \mathbf{5 5 0 0}$. Want f 15.000 verminderd met $f 5000$ (loon) $=$ f 10.000 , d.w.z. $5 \%$ van het kapitaal van 2 ton, en f 5500 eveneens verminderd met f 5000 (loon) $=$ f 500 , d.w.z. ook $5 \%$ over een kapitaal van $f$ 10000.- De nivelleering is dus tot stand gekomen; doordat, dank zij de verandering in de verhouding van voorraad en behoefte, in het eene bedrijf eenzelfde aantal arbeiders in denzelfden arbeidstijd voor $f 15.000$ waarde voortbrengt tegen - in het andere bedrijf een gelijk aantal arbeiders slechts voor $f \mathbf{5 5 0 0}$. Waarmede de arbeidswaarde door Marx zelf is opgeofferd.

Dat ten slotte de ervaring zijn theorie volslagen weerspreekt, kan één blik op de werkelijkheid lęeren. Vooreerst heeft men de afwijking, die monopoliegoederen, waartoe in dicht bevolkte landen alle grond behoort, vertoonen : zij zijn doorloopend meer waard, dikwijls véél meer, dan uit den besteden arbeid zou voortvloeien. En dan de afwijking der zeldzame, kostbare natuurgaven, waaraan; zooals zij daar zijn, geenerlei arbeid is. besteed, b.v. ertsbeddingen, natuurbosschen en -weiden enz. Hoe moet men verder aan met al die producten, waarin arbeid van hooger orde belichaamd is? Marx wil dezen arbeid herleiden tot gewonen handenarbeid, maar ziet voorbij, dat hij aldus, om de arbeidswaarde te redden, met ficties genoegen gaat. nemen. Wanneer het product van een beeldhouwer per uur tienmaal meer waard is dan dat van een steenhouwer, dan kan men wel voor de aardigheid volhouden, dat de kunstenaar tien gewone-werkmans-uren gearbeid 
heeft, in feite vulde hij er één met arbeid van hooger orde. Het is duidelijk, dat bij de belooning van dit soort werk het element van den tijd gecombineerd wordt met dat van de arbeidshoedanigheid, zoodat re vera de maatschappelijk noodwendige arbeidstijd als uitsluitende waardemaat wordt prijsgegeven. Het staat er mee geschapen als met een spoorwegtarief, dat volgens het afstandsbeginsel is samengesteld, - het beeld is van v. Böhm. In den weg bevindt zich een duur kunstwerk, een tunnel, een spoorwegbrug, 1 K.M. lang. Voor het tarief geldt dic K.M. er twee of drie. Nu wordt het afstandsbeginsel door een fictie zoogenaamd gehandhaafd, doch in werkelijkheid doorkruist door een geheel ander, nl. dat der aanlegkosten. Nog andere ,uitzonderingen" op den z.g. regel der arbeidswaarde zijn te noemen : hoe vaak blijkt achteraf een product den aangewenden arbeid niet waard, volkomen raadselachtig zoo de waarde in functioneel verband tot den arbeid stond. Hoe weinig zijn somstijds de producten van veel en intensief werken waard, men denke aan de huisindustrie en in het algemeen aan die gevallen, waarin de arbeid abnormaal laag wordt beloond. Dezelfde arbeid, op goeden en minder goeden grond, algemeen: onder goede en minder goede omstandigheden aangewend, brengt cen ongelijk product en ongelijke waarde voort. Misschien zegt men: dat ligt dan aan die omstandigheden en niet aan den arbeid. Volkomen waar, doch „men”, die dat zegt, is niet langer Marxist, want wanneer de arbeid alles ware .... Ten slotte is het ervaringsfeit, dat toekomstgoed minder waard is dan tegenwoordig goed, m.a.w. het heele rente-verschijnsel met de arbeidswaarde niet te rijmen. Men keere maar terug tot den 100 jarigen eik en het pas gepote eikenstekje: gelijke arbeid en toch .... De gevallen uit de praktijk des dagelijkschen levens liggen voor het grijpen, maar zooveel is nu toch wel duidelijk geworden, dat de uitzonderingen zóó talrijk en wat meer zegt zóó prìncipieel afwijkend zijn van de arbeidsthesis, dat, ook zuiver empirisch beschouwd, van deze als regel, als algemeene waarheid letterlijk niets overblijft.

De conclusie uit al het vooorgaande is niet moeilijk te trekken: het uitbuitingskarakter van rente en pachtwaarde, de noodzakelijkheid van uitzuiging van den arbeid- onder het kapitalisme gebannen naar het gebied der onbewezen beweringen, het geheele bouwsel van exploitatietheorie, opgetrokken op de meerwaardetheorie, die weer gebaseerd is op het leerstuk der arbeidswaarde 
door de critiek, die geen steen op den anderen liet, ingestort tot een puinhoop ! En dan de vraag: waar is de nieuwe socialistische leer, die vóór men gaat experimenteeren op het lichaam onzer maatschappij, voor eens en voor goed duidelijk maakt, dat de kwaal inhaerent is aan het organisme, dat herstel is uitgesloten en mitsdien het kapitalisme verdient af te sterven om plaats te maken voor een nieuwe economische wereldorde?

Wanneer socialisatie wilde zeggen, dat er bedrijven zijn, die in handen van de gemeenschap meer tot hun recht komen dan wanneer zij aan het particulier initiatief blijven overgelaten; dat er bedrijven zijn van zóó ingrijpende, vitale-beteekenis voor de volkshuishouding, dat $z \mathrm{ij}$ aan de particuliere ondernemers, al dan niet in kartel of trust vereenigd, zulk een overwicht verschaffen, dat de noodzakelijke harmonie tusschen bizonder en algemeen belang dreigt te loor te gaan, wie zou niet in beginsel met haar instemmen, wetende, dat over de grenzen viel te praten ? Reeds in 1874 heeft de eerlijke A. Schäffe het gezegd in zijn beroemde brochure „Die Quintessenz des Sozialismus”: „Der Untergang der höchsten und idealsten Güter der Zivilisation würde sich ganz gewiss an die wüst demokratisch-kommunistische Realisirung des Sozialismus anknüpfen. Solcher Untergang müsste aber nicht die Folge einer Gestaltung sein, bei welcher die Streitfrage zwischen dem dritten und vierten Stande auf ihren volkswirtschaftlichen Kern beschränkt und die Weiterentwicklung auf der Bahn stückweiser Reform und innerhalb des Ausmasses gesellschaftlich vorteilhafter Kollektivproduktion erhalten bliebe." Zoo is het inderdaad. Alles komt aan op een harmonisch in-elkaar-grijpen van particulier initiatief en gesocialiseerd bedrijf. De groote stuwkracht, die van eenzijdigheid uitgaat, welke eigen is aan elken ondernemersstand, ook dèn hoogstontwikkelden, moet zich verdragen met de altijd meer naar algemeene gezichtspunten georiënteerde socialisatie. Elke eenvormigheid echter is moordend, daar de vooruitgang op differentiatie berust, die ruimte laat voor de beste economische aanwending van alle energieën van lichaam èn van geest. Mr. Treub, in „Vragen van dezen Tijd," heeft gelijk, wanneer hij, sprekende van de ,prinsen van het bedrijfsleven" $0 . a$. zegt: „Een arend, opgesloten in de grootste kooi, die men zich voorstellen kan, is een ander en heel wat minder edel en forsch dier zelfs dan een valk die vrij kan rondvliegen." Echter zou ik, de beeldspraak voortzettend, willen aanvullen, dat de arend, in 


\section{4}

volstrekte vrijheid, ook meer onheil kan aanrichten dan het valkje, dat zijn slachtoffers onder de duiven zoekt. Het ware bedroevend zoo inderdaad het aldus gestelcie dilemma bestond: men zou nauwlijks weten, wat men moest kiezen. Het komt er echter op aan, den arend tot een terrein te bcperken, groot genoeg om van vrijheid van beweging te kunnen blijven spreken, een terrein waar zijn koninklijke eigenschappen de gemeenschap tot zegen zullen strekken. Hij worde geweerd van dat deel van het productieveld, waar zijn roofvogelnatuur per saldo to een dreiging zou worden. De moeilijkheid steekt in de grensbepaling. Alleen diepgaande studie van de sociaal-economische toestanden en verschijnselen, zonder politick vooroordcel ondernomen, zal hier tot bevredigende resultaten kunnen voeren. De totaal-indruk, die na lezing van het Rapport van de Socialisatie-commissie uit de S. D. A. P. achterblijft, is wel deze, dat er van burgerlijke zijde met de heeren te praten is: van beide kanten kan aan de brug worden gebouwd om de eenvoudige reden dat zoowel het absolute individualisme als het absolute socialisme aan innerlijke tegenstrijdigheid lijdt, die op straffe van schipbreuk dictrinaire consequentie te eenenmale verbiedt.

Groningen, April 1920.

H. W. C. BORDEWIJK. 